BIOFARM

Jurnal Ilmiah Pertanian

ISSN Print: 0216-5430; ISSN Online: 2301-6442

Vol. 16, No. 2, Oktober 2020

\title{
Pemanfaatan Gulma Mimosa invisa sebagai Pengendali Organisme Pengganggu Tanaman
}

\author{
Utilization of Mimosa invisa Weeds as Controllers of Plant Disturbing \\ Organisms
}

\author{
Risqa Naila Khusna Syarifah \\ Laboratorium Agronomi dan Hortikultura, Fakultas Pertanian, Universitas Jenderal Soedirman \\ *Korespondensi Penulis: risqanaila@unsoed.ac.id
}

\begin{abstract}
ABSTRAK
Kajian ini bertujuan untuk mengetahui pengaruh pemanfaatan ekstrak gulma Mimosa invisa L. sebagai pengendali organisme pengganggu tanaman. Hasil kajian menunjukkan bahwa pemanfaatan ekstrak gulma Mimosa invisa mampu menekan intensitas serangan hama, khususnya belalang dan putih palsu, serta intensitas infeksi patogen penyebab penyakit khususnya bercak cokelat dan hawar daun bakteri. Kandungan bahan kimia gulma ini berupa metabolit sekunder yang disebut mimosin, serta asam pipekolinat, tannin, alkaloid, saponin, triterpenoid, sterol, polifenol dan flavonoid. Adanya kandungan bahan kimia inilah yang mmendasari pemanfaatkan gulma $M$. invisa sebagai pestisida nabati. Berdasarkan beberapa penelitian, ekstrak dari batang dan daun Mimosa mampu mengendalikan pathogen penyebab antraknosa dan alternaria. Aplikasi akar Mimosa pada tanaman cabai juga mampu menekan sebaran penyakit pada buah dan daunnya.
\end{abstract}

Kata kunci: Mimosa invisa, pestisida, ekstrak gulma

\section{ABSTRACT}

This study aims to determine the effect of the use of Mimosa invisa L. weed extract as a control of plant-disturbing organisms. The results of the study showed that the utilization of Mimosa invisa weed extract was able to reduce the intensity of locust and fake white pests, as well as the intensity of pathogen infections causing brown spots and bacterial leaf blight. The chemical ingredients of this plant are mimosine compounds, pipekolinic acid, tannins, alkaloids, saponins, triterpenoids, sterols, polyphenols and flavonoids. The content of these compounds is then used as a vegetable pesticide. From some of the results of the study, the extracts of the daughter and daughter shame leaves were able to control antracnose and alternaria. Mimosa sp. Root extract application. in chili plants it turns out that it can reduce the incidence of disease in fruit and can reduce the severity of disease in leaves and fruit.

Keywords: Mimosa invisa, pathogen, pest, weed extract

\section{PENDAHULUAN}

Sektor pertanian berperan dalam memenuhi dan menunjang kebutuhan hidup manusia terutama bahan pangan, hortikultura dan perkebunan. Pestisida yang diaplikasikan pada tanaman budidaya digunakan untuk meningkatkan hasil dari praktik budidaya sebagai kegiatan pengendali Organisme Pengganggu Tanaman (OPT), termasuk di dalamnya hama, penyakit dan gulma (Olguin et al., 2007).

Penggunaan pestisida sebagai pengendali Organisme Pengganggu Tanaman (OPT) cukup efektif, namun di era masa kini semakin menimbulkan pengaruh yang mengkhawatirkan (Kartohardjono et al., 2009; Wiyono et al., 2014). Beberapa studi yang telah dilakukan menunjukkan bahwa penggunaan pestisida yang diaplikasikan pada padi digunakan dengan tingkat sangat tinggi, dapat melemahkan ketahanan ekosistem suatu wilayah karena matinya musuh alami, kerusakan keanekaragaman hayati mikroflora dan mesofauna serta rusaknya jaring-jaring makanan (Wiyono et al., 2014), juga berpengaruh buruk terhadap kesehatan manusia, kualitas lingkungan dan meningkatkan perkembangan populasi jasad pengganggu tanaman (Sunarno, 2000). Beruntungnya, penanganannya mulai mendapat perhatian pada beberapa dekade terakhir (Lalander et al., 2016).

Pemanfaatan bahan alami untuk mengendalikan OPT merupakan pilihan yang tepat untuk menekan penggunaan bahan kimia di sektor pertanian. Indonesia 
merupakan negara tropis yang kaya akan ragam hayati yang dapat dimanfaatkan secara maksimal sebagai pengendali OPT (Subagiya, 2013). Pemanfaatan bahan alami seperti jamur, nematoda, tumbuh-tumbuhan untuk mengendalikan OPT merupakan pilihan yang tepat untuk menekan penggunaan bahan kimia di sektor pertanian (Bonsignore and Vacante, 2012). Penggunaan tumbuhan, bahan tumbuhan, atau ekstrak tumbuhan (insektisida botani) untuk perlindungan tanaman dan cadangan produk bagi pengendalian serangga hama yang mampu dimanfaatkan oleh petani di masa kini yang cukup mampu diandalkan (Isman, 2008).

Beberapa agensia hayati juga mulai marak dikembangkan untuk mengendalikan hama dan penyakit tanaman yang berbasis ramah lingkungan. Kartohardjono et al. (2009) mengemukakan bahwa parasitoid $O$. malayensis mampu meningkatkan parasitoid terhadap telur walang sangit, jamur Beauveria bassiana (isolat Segunung) mampu mengendalikan hama kumbang moncong, kumbang mawar serta kutu daun (Djuanedi, 2009), serta bau-bauan dari tanaman Ceratophylum dan Lycopodium sangat menarik hama walang sangit dewasa sehingga dapat dikendalikan secara mekanis.

Biopestisida yang terbuat dari bahanbahan alam tidak mencemari lingkungan, yang diperoleh dari hasil ekstraksi bagian tertentu dari tanaman baik daun, buah, biji atau akar yang memiliki senyawa (metabolit sekunder) dan bersifat racun terhadap hama dan penyakit tertentu. Pemakaian bahanbahan alami secara terus-menerus juga diyakini tidak menimbulkan resistensi pada hama, seperti yang biasa terjadi pada pestisida sintetis. Djuanedi (2009) dalam penelitiannya mengemukakan bahwa biopestisida (ekstrak daun mimba, lengkuas dan serai) cukup efektif sebagai pengendali hama ulat, belalang dan thrips yang pembuatan dan aplikasinya di lapang cukup mudah dilakukan. Sumber bahan baku biopestisida juga cukup banyak yang mencapai 37.000 spesies flora di Indonesia dan baru sekitar satu persen yang dimanfaatkan. Lebih dari 30.000 jenis tumbuhan telah diidentifikasi sebagai gulma, 250 jenis dinyatakan sebagai gulma penting dan 80 jenis telah diketahui menurunkan hasil tanaman budidaya (Sulvetri et al., 2014).

Beberapa jenis gulma golongan rumput, teki dan gulma berdaun lebar berpotensi memiliki khasiat sebagai obat, namun ada pula yang mengandung racun terutama terhadap kulit dan sebagian lagi mempunyai bau yang menyengat dan digunakan untuk mengendalikan hama dan penyakit, seperti ekstrak kirinyu (Chromolaena odorata (L) untuk mengendalikan ulat grayak (Thamrin et al., 2013), ekstrak gulma siam untuk mengendalikan nimfa dan imago Heliopeltis spp. (Fitriana et al., 2012) dan meningkatkan komponen pertumbuhan tanaman kedelai (Kastono, 2005), serta ekstrak gulma babandotan (Ageratum conyzoides) untuk mengendalikan hama Sitophillus spp. pada benih jagung (Astriani, 2010).

Tanaman putri malu, atau Mimosa invisa (L.) termasuk famili Leguminoceae yang merupakan kerabat dekat Mimosa pudica (L.) dan sering disebut sebagai putri malu besar (Uluputty, 2014). Genus Mimosa dalam famili Mimosaceae (sinonim dari Leguminosae atau Fabaceae) merupakan tanaman yang banyak tersebar dan dikenal di seluruh dunia dengan jumlah spesies mencapai 300-500 (Baki et al., 1996). Polongpolongan ini telah banyak tumbuh di sebagian besar wilayah Asia, Afrika dan beberapa kepulauan pasifik termasuk Australia dan Papua Nugini yang berkembang mengalahkan vegetasi lainnya (Ekhator et al., 2013). Keberadaan tanaman ini cukup banyak tersebar di lahan yang tidak terpakai, juga beberapa pada lahan tanaman budidaya sebagai gulma yang keberadaannya merugikan.

Kandungan kimia dari tanaman ini adalah senyawa mimosin, asam pipekolinat, tannin, alkaloid, saponin, triterpenoid, sterol, polifenol, flavonoid, protein dan steroid (Kalabharathi et al., 2015; Rajendran and Krishnakumar, 2010; Ranjan et al., 2013). 
Kandungan senyawa inilah yang kemudian dimanfaatkan sebagai pestisida nabati. Dari beberapa hasil penelitian ekstrak akar dan daun putri malu ternyata mampu bekerja sebagai antimikroba yang dapat dimanfaatkan untuk menekan serangan hama dan atau penyakit tanaman (Tomar et al., 2014).

Tumbuhan putri malu besar tumbuh liar di tepi jalan, lapangan terlantar, dan tempattempat terbuka yang terkena sinar matahari, sehingga mudah ditemui. Tapi masih sedikit orang yang mengetahui bahwa putri malu mengandung senyawa aktif tannin dan mimosin yang mampu bersifat sebagai antimikroba (Syahid, 2009). Oleh karena itu, keberadaannya yang kurang menguntungkan secara langsung namun berlimpah dapat dimanfaatkan sebagai pengendali Organisme Pengganggu Tanaman.

Tujuan dilakukannya kajian ini adalah untuk mengetahui peran positif (manfaat) gulma Mimosa invisa sebagai pengendali Organisme Pengganggu Tanaman (OPT).

\section{PEMBAHASAN}

\section{Ekomorfologi Mimosa invisa}

Genus Mimosa L. tergolong famili Leguminosae yang merupakan tanaman asli Amerika Tenagah dan Selatan dengan pusat di Brasil yang terdiri dari 300-400 spesies di dunia. Hingga saat ini, belum banyak literur yang mengupas tentang bahan kimia dari Mimosa invisa ini. Adapun kerabat dekatnya, Mimosa pudica L. telah banyak dikaji dan diketahui mengandung senyawa fenol dan memiliki gerak niktinasti pada daunnya dan diketahui bahwa flavonoid merupakan senyawa yang cukup dominan yang terkandung pada genus Mimosa (Aguiar, 2012).

Tanaman putri malu, atau Mimosa invisa (L.) termasuk family Leguminoceae yang merupakan kerabat dekat Mimosa pudica (L.) dan sering disebut sebagai putri malu besar. Tumbuhan berupa perdu, umumnya tumbuh menjalar di atas tanah, batangnya bersegi, berduri, dan panjangnya mencapai $6 \mathrm{~m}$ dan biasanya dijadikan penutup tanah. Tumbuh di tempat terbuka atau terlindung, dengan ketinggian tempat hingga $1.000 \mathrm{~m}$ dpl (Uluputty, 2014).

Tanaman ini berbentuk semak belukar, dan menyerupai tanaman tahunan pada tahun/musim tertentu karena berumur panjang. Batang berbentuk tandan, segiempat, bercabang, berduri tempel atau rapat dan merupakan kompetitor yang kuat bagi tanaman lain. Daun majemuk, berselangseling, panjang 3-8 mm, lebar 1-1,5 mm, tepi rata, ujung runcing, pertulangan tidak jelas, berwarna hijau terang dan berduri. Setiap daun terdiri dari lima sampai tujuh pasang segmen. Setiap segmen terdiri dari dua puluh pasang daun kecil yang mampu menutuk ketika menerima rangsangan, tergores atau ketika malam hari. Bunga berwarna merah jambu (pink), berukuran kecil, berbentuk bulat, mengembang dengan diameter sekitar $12 \mathrm{~mm}$, memiliki tangkai pendek pada ketiak daun, berjumlah satu sampai tiga, benangsari delapan, mahkota berbentuk tabung. Polong berambut, berkelompok dengan panjang masing-masing sekitar $25 \mathrm{~mm}$ dan lebar 6 $\mathrm{mm}$ saat matang, berwarna kuning kecokelatan. Biji berbentuk bulat, permukaan licin, keras dan berwarna kuning kecokelatan. Akar berwarna putih dan tunggang serta terdapat bintil akar.

Tanaman tahunan yang biasanya berbunga dan berbiji pada bulan April sampai akhir Juni. Pada tahun-tahun dengan musim dingin atau penghujan, tanaman ini akan berkurang, dan akan berbiji mulai bulan April sampai Desember (membutuhkan waktu hidup yang lebih panjang) (Department of Agriculture and Fisheries, 2016). 

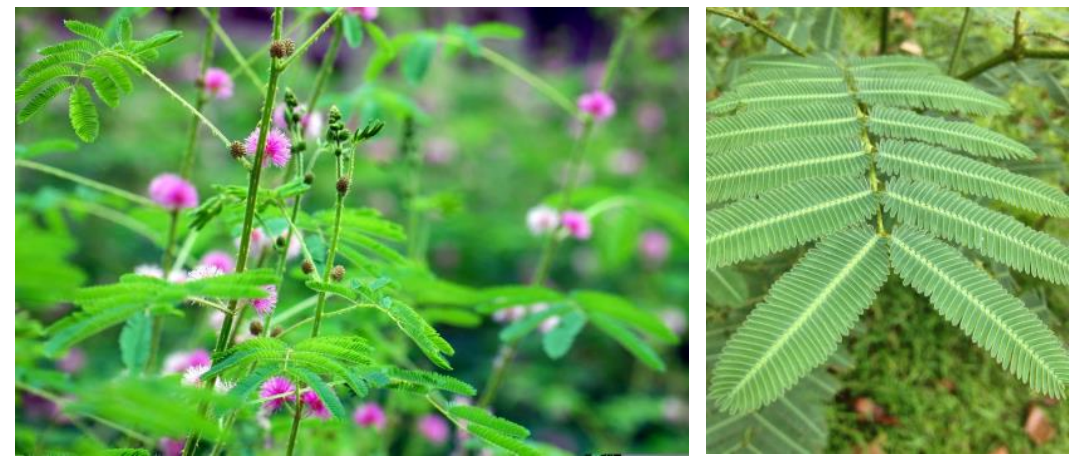

Gambar 1. Gulma Mimosa invisa

Mimosa invisa mempunyai kekerabatan dengan putri malu (Mimosa pudica) dan daun yang juga dapat menutup seperti pada Mimosa pudica. Namun memiliki kecepatan rangsang berbeda (lebih lambat). Selain itu, Mimosa invisa memiliki duri yang lebih rapat dan jika tertusuk duri tersebut dapat menyebabkan pembengkakan pada jaringan tubuh.

2. Kandungan kimia dan potensi mimosa invisa sebagai pestisida nabati

Mimosa invisa tergolong tanaman Leguminosae yang memiliki senyawa fenolik dalam konsentrasi yang tinggi, khususnya tanin dan mimosin yang terkandung pada daun (Jayanegara dan Sofyan, 2008). Hasil penapisan fitokimia simplisia dan ekstrak herba putri malu menunjukkan adanya golongan senyawa mimosin, tanin, flavonoid, alkaloid, saponin, polifenol, monoterpenoid, seskuiternoid, steroid, dan kuinon. Menurut seorang herbalis sekaligus terapis Natura Health Centre di Depok, Jawa Barat, putri malu mengandung melatonin. Menurutnya senyawa yang paling berkhasiat adalah melatonin yang memberi efek relaksasi pada syaraf otak kecil (Haq, 2009). Ekstrak daun putri malu diketahui dapat meningkatkan enzim antioksidan seperti Superoxide Dismutase (SOD), Catalase, dan Glutathion Peroxidase (Rini et al., 2013).

Mimosin adalah asam amino yang bersifat toksik (Candra et al., 2008). Mimosin merupakan golongan asam amino aromatik dengan rumus kimia ( $\beta-\mathrm{N}$-(3-hydroxy-4pyridone)- $\alpha$-amino-propenoic acid). Mimosin adalah asam amino non protein yang mempunyai struktur hampir sama dengan tirosin, serta terdapat pada beberapa spesies mimosa dalam genus Leucaena. Mimosin ( $\beta$ $\mathrm{N}$-(3-hydroxy-4-pyridone) mengandung senyawa polifenol yang tinggi termasuk tanin akan mengikat protein, sehingga protein menjadi tidak tersedia untuk binatang yang memakan tumbuhan tersebut dan menyebabkan efek negatif terhadap palatabilitas, kecernaan, dan pertumbuhan. Mimosin akan mempengaruhi sintesis dan atau fungsi protein dalam mengatur translasi mRNA yang menyebabkan penghambatan replikasi DNA (Laconi dan Widiyastuti, 2010).

Mimosin pada tingkat molekul akan berfungsi sebagai antagonis tirosin yang dapat menghambat kerja tirosin dan kegunaan enzim. Secara umum efek negatif mimosin adalah kehilangan nafsu makan, pembesaran kelenjar gondok, performa reproduksi buruk, menekan pertumbuhan, dan kematian post-natal. Mimosin dapat menyebabkan defisiensi glisina, salah satu asam amino essensial bagi unggas, untuk mensintesis asam empedu sehingga absorbsi lemak menurun yang pada akhirnya akan menyebabkan defisiensi vitamin dan pigmen larut lemak. Hal ini diduga dapat menghambat perkembangan hama pada tanaman yang mampu menurunkan produksi dan mengganggu pertumbuhan tanaman budidaya (Laconi dan Widiyastuti, 2010).

Selain mimosin sebagai unsur utama ekstrak akar tanaman putri malu juga mengandung $10 \%$ tanin, daunnya mengandung tanin dalam persentase yang lebih rendah. Tanin adalah senyawa polifenol yang secara alami terdapat pada tanaman leguminosa. Tanin tidak dapat dicerna 
lambung dan memiliki efek antinutrisi berupa kemampuannya berikatan kuat dengan protein dan derivatnya (enzim), karbohidrat, vitamin, dan mineral. Kehadiran tanin akan mengikat unsur tersebut sehingga tidak dapat diserap dan kemudian mengeluarkannya bersama feses (Candra et al., 2008).

Flavonoid merupakan salah satu kelompok senyawa metabolit sekunder yang paling banyak ditemukan di dalam jaringan tanaman. Flavonoid termasuk dalam golongan senyawa phenolik dengan struktur kimia C6-C3-C6. Kerangka flavonoid terdiri atas satu cincin aromatik $A$, satu cincin aromatik $\mathrm{B}$, dan cincin tengah berupa heterosiklik yang mengandung oksigen dan bentuk teroksidasi cincin ini dijadikan dasar pembagian flavonoid ke dalam sub-sub kelompoknya (Hess, tt). Sistem penomoran digunakan untuk membedakan posisi karbon di sekitar molekulnya (Redha, 2010).

Senyawa golongan flavonoid yang mempunyai aktivitas insektisida yang berasal dari tanaman di antaranya adalah rotenon dan deguelin yang terdapat pada tumbuhan Lonchocarpus utilis, kuersetin 3,7,4-trimetil eter yang terdapat pada tumbuhan Saccopetalum horsfieldii dan mirisetin 3-metil eter dari Goniothalamus thwatesii (Diantoro et al., 2010).

Terpenoida adalah merupakan komponen-komponen tumbuhan yang mempunyai bau dan dapat diisolasi dari bahan nabati dengan penyulingan disebut sebagai minyak atsiri (Lenny, 2006). Senyawa terpenoid dapat menyebabkan kematian pada hama uji dan juga dapat mengurangi aktivitas makan (Bahri dan Rinawati, 2005). Senyawa terpenoid yang mempunyai aktivitas insektisida yang telah berhasil ditemukan dalam tanaman antara lain piretrin dari beberapa spesies Chrysanthemum, camphene dan azadirachtin yang berasal dari famili Meliaceae dan Rutaceae (Diantoro et al., 2010).

Alkaloid merupakan senyawa antibakteri yang mengandung nitrogen yang bersifat basa dan mempunyai aktifitas farmakologis (Lumbanraja 2009 dalam
Rohyani et al., 2015). Bagi tumbuhan, alkaloid berfungsi sebagai senyawa racun yang melindungi tumbuhan dari serangga atau herbivora (hama dan penyakit), pengatur tumbuh atau sebagai basa mineral untuk mempertahankan keseimbanagan ion. Umumnya alkaloid merupakan senyawa padat, berbentuk kristal, tidak berwarna dan mempunyai rasa pahit, sedangkan daun pegagan memiliki sifat manis dan sejuk. Alkaloid umumnya tidak ditemukan pada gymnospermae, paku-pakuan, lumut dan tumbuhan rendah lainnya (Rohyani et al., 2015).

Saponin merupakan suatu glikosida yaitu campuran karbohidrat sederhana dengan aglikon yang terdapat pada bermacam-macam tanaman. Saponin dibedakan berdasarkan hasil hidrolisisnya menjadi karbohidrat dan sapogenin, sedangkan sapogenin terdiri dari dua golongan yaitu saponin steroid dan saponin triterpenoid. Saponin banyak dipelajari terutama karena kandungannya kemungkinan berpengaruh pada nutrisi. Saponin mudah larut dalam air dan tidak tarut dalam eter, memiliki rasa pahit menusuk dan menyebabkan bersin serta iritasi pada selaput lendir. Saponin merupakan racun yang dapat menghancurkan butir darah atau hemolisis pada darah, bersifat racun bagi hewan berdarah dingin (Rachman et al., 2011).

Penerapan sistem pertanian dengan mengkombinasikan teknologi penggunaan biopestisida dan pupuk hayati mempunyai prospek untuk meningkatkan daya dukung lahan, optimalisasi penggunaan pupuk dan menekan serangan penyakit tular tanah (Prabowo, 2008). Dalam perakaran putri malu terdapat bintil-bintil akar yang mengandung koloni mikroba yang bersimbiosis mutualisme dengan akar putri malu tersebut. Beberapa mikroba yang terkandung dalam akar putri malu antara lain Rhizobium, Bacillus sp., Pseudomonas putida dan Actinomycetes. Putri malu juga banyak dimanfaatkan sebagai pestisida nabati. Bagian tanaman yang dimanfaatkan sebagai pestisida nabati yaitu akar, batang dan daun (Vikayanti, 2011). 
Kandungan kimia dari tanaman ini adalah senyawa mimosin, asam pipekolinat, tannin, alkaloid, saponin, triterpenoid, sterol, polifenol dan flavonoid. Kandungan senyawa inilah yang kemudian dimanfaatkan sebagai pestisida nabati. Dari beberapa hasil penelitian ekstrak akar dan daun putri malu ternyata mampu mengendalikan penyakit atraknosa dan alternaria. Aplikasi ekstrak akar Mimosa sp. pada tanaman cabai ternyata dapat menekan insidensi penyakit pada buah dan mampu menekan keparahan penyakit pada daun dan buah (Vikayanti, 2011).

Pemanfaatan Mimosa invisa sebagai pestisida nabati dapat dilakukan dengan pembuatan ekstraksi tanaman tersebut dengan metode maserasi. Bahan sampel berupa daun putri malu segar dibersihkan kemudian dikeringkan dalam oven selama satu hari dengan suhu $37^{\circ}$. Setelah kering daun putri malu dibuat menjadi serbuk dengan menggunakan blender. Serbuk yang telah halus ditimbang sebanyak 100 gram kemudian dilarutkan dalam pelarut etanol $80 \%$ sebanyak $1000 \mathrm{ml}$, kemudian ditambahkan $200 \mathrm{ml}$ akuades. Larutan dibiarkan selama satu minggu sambil diaduk selama 15 menit setiap hari. Selanjutnya larutan disaring dengan menggunakan kertas saring untuk menghasilkan filtrat. Hasil saringan dituang kedalam cawan petri lalu dikeringkan selama \pm dua hari dengan suhu $37^{\circ}$ untuk menguapkan etanol sehingga dengan demikian diperoleh ekstrak daun kering. Pembuatan larutan uji dengan berbagai tingkat konsentrasi yaitu: 100\%, $50 \%$, dan $33 \%$, diperoleh dari 1 gram ekstrak daun kering ditambahkan masing-masing akuades sebanyak $1 \mathrm{ml}, 2 \mathrm{ml}$, dan $3 \mathrm{ml}$ (Mehingko et al., 2010).

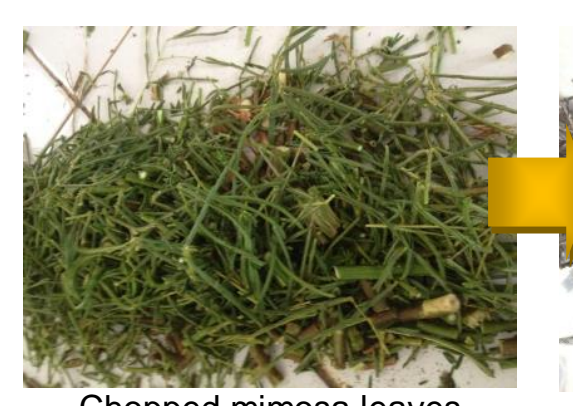

Chopped mimosa leaves

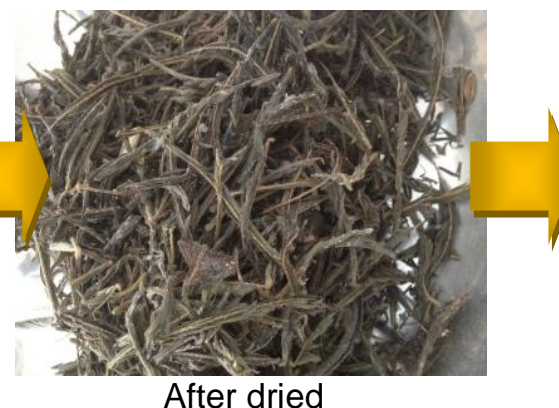

After dried

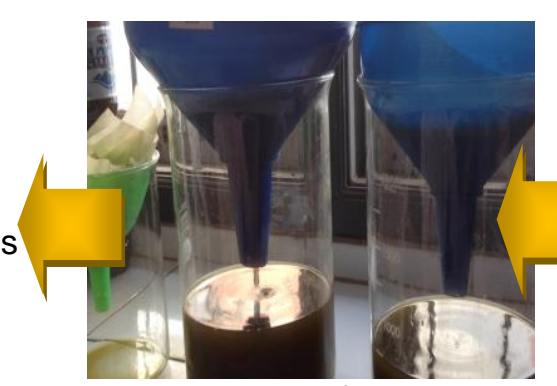

The extract is ready to be applied with concentration as needed

\section{Filtered using filter paper \\ Gambar 2. Proses pembuatan ekstrak Mimosa invisa ethanol and distilled water \\ Maceration in a solution of}

Ekstrak daun putri malu menghambat pertumbuhan lima jenis bakteri uji yaitu Enterobacter cloacae, Pseudomonas aeuruginosa, Proteus stuarti, Escherichia coli, dan Staphylococcus aureus dengan terlihat adanya zona hambat di sekitar sumur media uji (Mehingko et al., 2010). Aguiar (2012), mengemukakan bahwa batang Mimosa invisa mengandung flavonoid yang mampu berperan sebagai antioksidan dan antimikroba dari 
tanaman tersebut. Ekstrak putri malu memiliki aktivitas antimikroba yang dapat menghambat pertumbuhan bakteri Bacillus subtilis, Pseudomonas aeruginosa, Klebsiella pneumonia, jamur Aspergillus flavus dan jamur Trycophyton ruburum secara in vitro pada konsentrasi 25, 50, 75 and $100 \mu \mathrm{l} /$ cawan petri (Tamilarasi and Ananthi,2012).

\section{KESIMPULAN}

Mimosa invisa merupakan gulma yang banyak tersebar di hamparan dan kurang dimanfaatkan secara optimal. Kemampuannya berkompetisi dengan tumbuhan lain (tanaman budidaya maupun gulma) tergolong baik karena senyawa metabolit sekunder yang dimilikinya yang mampu membuatnya tetap bertahan hidup. Tumbuhan ini dapat dimanfaatkan sebagai pestisida nabati melalui cara ekstraksi. Ekstrak Mimosa invisa mengandung senyawa kimia seperti mimosin, tanin, flavonoid, alkaloid, terpenoid dan saponin yang bersifat anti-hama, antibakteri dan antifungal untuk mengendalikan organisme pengganggu tanaman (hama, patogen dan gulma).

\section{DAFTAR PUSTAKA}

Aguiar, R. M. 2012. Antioxidant Activities of Isolated Compounds from Stems of Mimosa invisa Mart. Ex. Colla. Quinn Nova. No. 3(35):567-570.

APFISN (Asia - Pacific Forest Invasive Species Network. 2009. "Mimosa diplotricha Giant Sensitive Plant". Invasive Pest Fact Sheet. (On-line). http://www.fao.org/forestry/133770977cb34791475aa6a7a360640f09778 .pdf diakses 21 Februari 2017.

Astriani, D. 2010. Pemanfaatan Gulma Babadotan dan Tembelekan dalam Pengendalian Sitophillus spp. pada Benih Jagung. Jurnal AgriSains. 1(1):56-67.

Bahri, S. dan Rinawati. 2005. Senyawa Terpenoid Hasil Isolasi dari Daun Lada (Piper nigrum, Linn) dan Uji Bioktivitasnya terhadap Hama Callosobruncus chinensis. Jurnal Sains Teknik. No.3(11):158-166.
Baki, B. Bakar, H. Noormawati dan M. A. H. Mohamed. 1996. The Genus Mimosa with Special Reference Tom. Quadrivalvis L. Var Leptocarpa (D.C.) Earnedy, A New Species Record for the Weed Flora in Malaysia. Biotropia. 9:38-52.

Bonsignore, C. P. and V. Vacante. 2012. Influences of Botanical Pesticides and Biological Agents on Orius laevigatus Frankliniella occidentalis Dynamics under Greenhouse Conditions. Journal of Plant Protection Research. 1(52):1523.

Candra, A. A., Y. Ridwan dan E. B. Retnani. 2008. Potensi Anthelmintik Akar Tanaman Putri Malu (Mimosa pudica L.) terhadap Hymenolepsis nana pada Mencit. Media Peternakan. No. 1(31):29-35.

Department of Agriculture and Fisheries. 2016. Giant Sensitive Plant, Mimosa diplotricha $=$ Mimosa invisa. Biosecurity Queensland. The State of Queensland, Department Agriculture and Fisheries. 4 pages.

Diantoro, N. S., E. Faridah dan N. Rismawati. 2010. Pemanfaatan Senyawa Flavonoid dari Tumbuhan Goniothalamus macrophyllus sebagai Biolarvasida dan Pengendalian Hama yang Ramah Lingkungan. Universitas Airlangga, Surabaya. 5 hal.

Ekhator, F., O. O. Uyi, C. E. Ikuenobe and C. O. Okeke. 2013. The Distribution and Problems of the Invasive Alien Plant, Mimosa diplotricha C. Wright ex Sauvalle (Mimosaceae) in Nigeria. American Journal of Plant Sciences. 4:866-877.

Fitriana, Y., Purnomo dan A. M. Hariri. 2012. Uji Efikasi Ekstrak Gulma Siam terhadap Mortalitas Hama Pencucuk Buah Kakao (Helopeltis spp.) di Laboratorium. Jurnal HPT Tropika. 1(12):85-91.

Haq, A. S. 2009. Pengaruh Ekstrak Herba Putri Malu (Mimosa pudica Linn.) terhadap Efek Sedasi pada Mencit BALB/C. Laporan Hasil Akhir Penelitian Karya Tulis IImiah. Fakultas 
Kedokteran, Universitas Diponegoro, Semarang. 53 hal.

Isman, M. B. 2008. Perspective Botanical Insecticides: for Richer, for Poorer. Pest Management Science. 64:8-11.

Jayanegara, A. dan A. Sofyan. 2008. Penentuan Aktivitas Biologis Tanin Beberapa Hijauan secara in Vitro Menggunakan 'Hohenheim Gas Test' dengan Polietilen Glikol sebagai Determinan. Media Peternakan. No. 1(31):44-52.

Kalabharathi, H.L., Shruthi S. L., Vaibhavi P. S., Pushpa V. H., Satish A. M. and M. Sibgatullah. 2015. Diuretic Activity of Ethanolic Root Extract of Mimosa pudica in Albino Rats. Journal of Clinical and Diagnostic Research. 9(12):5-7.

Kartohardjono, A., D. Kertoseputro dan T. Suryana. 2009. Hama Padi Potensial dan Pengendaliannya. Balai Besar Penelitian Tanaman Padi. 36 hal.

Kastono, D. 2005. Tanggapan Pertumbuhan dan Hasil Kedelai Hitam terhadap Penggunaan Pupuk Organik dan Biopestisida Gulma Siam (Chromolaena odorata). Jurnal IImu Pertanian. 2(12):103-116.

Laconi, E. B. dan T. Widyastuti. 2010. Kandungan Xantofil Daun Lamtoro (Leucaena leucocephala) Hasil Detoksikasi Mimosin Secara Fisik dan Kimia. Media Peternakan. No. 1(33):5054.

Lalander, C., J. Senecal., M. G. Calvo, L. Ahrens, S. Josefsson, K. Wiberg and B. Vineras. 2016. Fate of Pharmaceuticals and Pesticides in Fly Larvae Composting. Science of the Total Environment. 565:279-286.

Lenny, S. 2006. Senyawa Terpenoida dan Steroida. Karya IImiah. Fakultas MIPA, Universitas Sumatera Utara, Medan. 25 hal.

Lumbanraja, L. B. 2009. Skrinning Fitokimia dan Uji Efek Antiinflamasi Ekstrak Etanol Daun Tempuyung (Sonchus arvensis L.) terhadap Radang pada
Tikus. Skripsi. Fakultas Farmasi, Universitas Sumatera Utara. 83 hal.

Mehingko, L., H. Awaloei dan M. P. Wowor. 2010. Uji Efek Antimikroba ekstrak Daun Putri Malu (Mimosa pudica Duchaas \& Walp) secara in Vitro. Bagian Farmakologi dan Terapi, Fakultas Kedokteran, Universitas Sam Ratulangi Manado. 6 hal.

Olguin, S. E., A. Espinoza G. and E. Esquivel A. M. 2007. Vegetative and Reproductive Development of Costa Rican Weedy Rice Compared with Commercial Rice (Oryza sativa). Planta Daninha, Vicosa MG. 1(25):13-23.

Prabowo, R. 2008. Kajian Biopestisida dan Pupuk Hayati dalam Mendukung Pengelolaan Tanaman Tomat Secara Terpadu. Jurnal Mediagro. 1(4):81-88.

Rachman, A., S. Wardatun dan I. Y. Weandarlina. 2011. Isolasi dan Identifikasi Senyawa Saponin Ekstrak Metanol Daun Binahong (Anredera cordifolia (Ten.) Steenis). Fakultas MIPA, Universitas Pakuan, Bogor. 6 hal.

Rajendran, R. and E. Krishnakumar. 2010. Hypolipidemic Activity of Chloroform Extract of Mimosa pudica Leaves. Avicenna Journal of Medical Biotechnology. 4(2):215-221.

Ranjan, R. K., M. S. Kumar, I. Seethalakshmi and M. R. K. Rao. 2013. Phytocemical Analysis of Leaves and Roots of Mimosa pudica Collected from Kalingavaram, Tamil Nadu. Journal of Chemical and Pharmaceutical Research. 5(5):53-55.

Redha, A. 2010. Flavonoid: Struktur, Sifat Antioksidatif dan Peranannya dalam Sistem Biologis. Jurnal Berlian. No. 2(9):196-202.

Rini, A. S., Hairrudin dan Sugiyanta. 2013. Efektivitas Ekstrak Putri Malu (Mimosa pudica Linn.) sebagai Nefroprotektor pada Tikus Wistar yang Diinduksi Parasetamol Dosis Toksik. Jurnal Pustaka Kesehatan. 1(1):15-19. 
Rohyani, I. S., E. Aryanti dan Suripto. 2015. Kandungan Fitokimia Beberapa Jenis Tumbuhan Lokal yang Sering Dimanfaatkan sebagai Bahan Baku Obat di Pulau Lombok. Prosiding Seminar Nasional Masyarakat Biodiversitas Indonesia. No. 2(1):388391.

Subagiya. 2013. Kajian Efektifitas Pengendalian Hama Padi Secara Alami dengan Semut Predator yang Bersarang di Tanah (Solenopsis geminata (F)). Program Studi Agroteknologi, Fakultas Pertanian, Universitas Sebelas Maret Surakarta. 8 hal.

Subagiya. 2013. Kajian Efektifitas Pengendalian Hama Padi Secara Alami dengan Semut Predator yang Bersarang di Tanah (Solenopsis geminata (F)). Program Studi Agroteknologi, Fakultas Pertanian, Universitas Sebelas Maret Surakarta. 8 hal.

Sulvetri, B. Z. Syam dan Solfiyeni. 2014. Analisa Vegetasi Gulma pada Pertanaman Jagung (Zea mays L.) pada Lahan Olah Tanah Maksimal di Kabupaten Lima Puluh Kota. Jurnal Biologi Universitas Andalas. No. 3(2):103-108.

Sunarno. 2000. Pengendalian Hayati (Biologi Control) sebagai Salah Satu Komponen Pengendalian Hama Terpadu (PHT). (On-line).

http://journal.uniera.ac.id/pdf repository juniera31uHlhqLaBkzzrDBMOhRadqxY8H.pdf diakses 7 Maret 2017. 12 hal.
Syahid, M. A. 2009. Pengaruh Ekstrak Putri Malu (Mimosa pudica, Linn.) terhadap Mortalitas Ascaris suum, Goeze in Vitro. Skripsi. Fakultas Kedokteran, Universitas Sebelas Maret, Surakarta. 42 hal.

Tamilarasi, T. and Ananthi T. 2012. Phytochemical Analysis and Anti Microbial Activity of Mimosa pudica Linn. Research Journal of Chemical Sciences. No. 2(2):72-74.

Thamrin, M., S. Asikin dan M. Wilis. 2013. Tumbuhan Kirinyu Chromolaena odorata (L) (Asteraceae: Asterales) sebagai Insektisida Nabati untuk Mengendalikan Ulat Grayak Spodoptera litura. Balai Penelitian Pertanian Lahan Rawa. Banjarbaru.

Tomar, R. S., V. Shrivastava and S. Kaushik. 2014. In Vitro Efficacy of Methanolic Extract of Mimosa pudica Against Selected Micro-organisms for Its Broad Spectrum Antimicrobial Activity. International Journal of Current Microbiology and Applied Sciences. 3(4):780-784.

Uluputty, M. R. 2014. Gulma Utama pada Tanaman Terung di Desa Wanakarta Kecamatan Waeapo Kabupaten Buru. Jurnal Agrologia. 1(3):37-43.

Vikayanti. 2011. Menilik Potensi Sang Putri Malu. Balai Perbenihan dan Proteksi Tanaman Perkebunan, Surabaya.

Wiyono, S., Widodo dan H. Triwidodo. 2014. Mengelola Ledakan Hama dan Penyakit Padi Sawah pada Agroekosistem yang Fragil dengan Pengendalian Hama Terpadu Biointensif. Risalah Kebijakan Pertanian dan Lingkungan. 2(1):116120. 